\title{
PHYSIOLOGICAL AND HYGIENIC ASSESSMENT OF WORK CONDITIONS AND STATE OF HEALTH OF ELECTRIC TRAIN DRIVERS AND THEIR ASSISTANTS ON UIRAINIAN RAILWAY
}

\author{
Yavorovskyi A. P.', Tkachishina N. Yu.' ${ }^{2}$, Kaznodiy A. V.'
}

'O. O. Bogomolets National Medical University, Kyiv

\section{${ }^{2}$ Kyiv Railway Clinical Hospital № 2}

Introduction. At the present stage, workers of locomotive brigades perform the main function of the transport industry - uninterrupted movement of transportation of passengers and different loads with high responsibility. The technology of the productive process on railway determines availability of a combination of harmful factors at workplaces in the production environment and work processes.

The purpose of the study was to assess working conditions of electric train drivers (ETD) and their assistants by severity and intensity of the working process, harmfulness and danger of factors of the work environment; and, using modern methods of mathematical analysis to develop a prognostic model for a comprehensive assessment of the effect of harmful factors of the production environment and work process as risk factors in development of pathological changes in the body of workers, cardio-vascular diseases (CVD), in particular.

Materials and methods. Hygienic studies and assessment of work conditions were conducted in accordance with the normative documentation. Clinical and instrumental studies were performed with the use of modern diagnostic equipment. For prognostic assessing of development of pathology of the cardiovascular system (CVS), depending on the availability of individual clinical or production risk factors, a prognostic model of statistically significant risk factors has been developed with the assessment of their odds ratios and the following their generalization by principles of meta-analysis and determination of heterogeneity of the effect (Higgins's I2 test) on the health of workers.

Results. According to the results of studies on drivers and their assistants their work can be referred to Class 3.2., Hygienic Classification of Work, 2014. The degree of expressiveness of pathological changes in ETD and their assistants was determined in corresponding sub-groups depending on the work experience. The most predicted nosologies in workers were: hypertension, metabolic syndrome, nonalcoholic fatty liver disease as well as comorbid pathology on the background of vegetative disfunction, being the basis for development of hepatocardial continuum. A prognostic estimation is presented in relation to the increase of the reliability in developing pathology of the CVS. A differentiation of dispensary groups and corresponding medical measures for workers were undertaken depending on the work experience.

Conclusion. A wide implementation into practice of preventive measures, depending on the differentiation of dispensary groups, will enable to effectively decrease risks of developing pathological changes with account of the work experience.

Key words: electric train drivers, work conditions, state of health

\section{Introduction}

At the present stage, professions of drivers and their assistants, who are employees of locomotive brigades, are one of the most important on railway, requiring high responsibility, as they are namely those who perform the main function of the transport industry provide for uninterrupted traffic of transporting passengers and various goods.

The technology of the production process on the railway transport determines the presence of a combination of harmful factors of the production environment and labor process at workplaces of electric train drivers (ETD) [1-3].
Such harmful factors of working conditions as high nervous and emotional stress, dangerous situations, responsibility for others, focused work, attention to devices, hypodynamics, noise, vibration, infrasound and others, can cause the development of cardiovascular diseases (CVD) [4, 5] and pathology of the digestive system [6].

In the analysis of morbidity of workers, who are exposed to the above harmful and dangerous factors, it is established that a large number of diagnoses is of a combined character $[7,8]$.

The limited physical activity, imbalanced schedule of work and rest, malnutrition can be the reason of metabolic disorders and overweight $[9,10]$. 
ISSN 2223-6775, Ukrainian Journal of Occupational Health, 2020, 16 (2), 96-103

Metabolic disorders and related pathological states are significantly prevalent among ETD [11]. The initial manifestations like carbohydrate and lipid metabolism disorders are objective characteristics of pre-diabetic and pre-atherosclerotic states, proven risk factors for development of CVD, which worsen living conditions and are the main causes of mortality at present.

To date, a number of problems remain unresolved in assessing the severity and intensity of work of electric train drivers and their assistants; the state of their health depending on the experience and working conditions has not been studied; criteria for pre-nosological disorders in functioning of the body of working people are not defined; no correlation has been established between risk factors, working conditions, work experience and appearance of signs of health disorders in ETD for prognostic assessment of their impact on the development of CVD.

The purpose of the study was to assess working conditions for electric train drivers and their assistants by severity and intensity of the work process, harmfulness and danger of factors of the work environment; and, using modern methods of mathematical analysis to develop a prognostic model for a comprehensive assessment of the effect of harmful factors of the production environment and the work process as risk factors in developing pathological changes in the body of workers, cardio-vascular diseases (CVD), in particular.

\section{Materials and methods}

514 people took part in the research. The main group included 398 ETD with more than one year of work experience, aged 19-61, exposed to a combination of harmful production factors in performance of their official duties.

The control group, similar in its main parameters (gender, age, work experience), consisted of 116 engineering and technical workers (ETW) on railway, who were not exposed to harmful production factors in the work process.

To conduct research, subgroups (SG) were formed, depending on the work experience: SG1 - with work experience $<10$ years, SG2 - with work experience of $11-20$ years, SG3 - with work experience of $21-30$ years, SG4 - with work experience $>30$ years.

Hygienic studies and determination of working conditions were conducted in accordance with regulations: 1) «Mechanical vibration. Laboratory method for estimating vibration of a vehicle seat. Railway vehicles» (ISO 10326-2:2001, IDT); 2) SSN 3.3.6.037-99 «State sanitary norms on industrial noise, ultrasound and infrasound»; 3) Regulation document 63.21-1.17-08 «Rules for safe operation of electric locomotives, diesel locomotives and motorwagon vehicles», dated 24.03.2008, № 54; 4) SSN 3.3.6.096-2002 «State sanitary norms of non-ionizing electromagnetic radiation»; 5) «Hygienic classification of work by indicators of harmful and dangerous factors of the production environment, severity and intensity of the labor process (HCW)», Order № 248 of the Ministry of Health of Ukraine, April 8, 2014.

Clinical and instrumental studies were conducted on the basis of the Clinical Hospital № 2 of Ukrainian railway, Kyiv. The study of the anamnesis of both groups (ETD and ETW) was conducted by interviewing and by the data of outpatient cards; determination of the level of stress resistance - by Spielberger method.

The objective examination included a general examination of patients to determine anthropometric parameters. Ultrasound examinations were performed using ultrasound devices «Vivid-7 Pro» («General Electric», USA), «Sonomed-300» (Ukraine); daily blood pressure monitoring (DBPM) and its variability - by Meditech Cardio Tens complex (Hungary) with Medibase program; study of the heart rate variability (HRV) and bicycle ergometry (BEM) with a complex of diagnosticautomated «Cardio + $(\mathrm{NPP} \ll M E T E K O L »$, Ukraine); capillaroscopywith the device «Capillaroscope $M-70 A »$. The total number of studies in the main and control groups made 9500 .

To forecast the probability of CVS pathology, depending on the availability of individual clinical or production risk factors, a prognostic model of statistically significant risk factors has been developed with the assessment of the odds ratio (OR) and $95 \%$ confidence interval, followed by generalization, based on meta-analysis and heterogeneity of the effect (Higgins's I2 test) on the drivers' health. A statistical analysis was made using a licensed statistical package SPSS Statistics 22.0.

\section{Results and discussion}

The hygienic studies have shown that at workplaces of drivers there is a combined effect of factors of the working process, and their work by the criteria of Hygienic Classification of Work, as regards the heaviness of work, can be referred to Class 3.2 (harmful, hard, $2^{\text {nd }}$ degree) by the indicator «work posture» 
(staying $93,52 \%$ of the time of a work shift in an awkward position, which is $68,0 \%$ higher than the norm) in conditions of hypodynamia (moving for $0,3 \mathrm{~km}$ horizontally within a work shift, the norm is up to $8,0 \mathrm{~km}$ ); by intensity of work - to Class 3.2 (harmful, intensive, $2^{\text {nd }}$ degree) by indicators: sensory loads on the auditory analyzer, intellectual loads, emotional loads, shift work (irregular, 2-3 shift work with a night shift); by factors of the production environment - to Class 3.2 (harmful, $2^{\text {nd }}$ degree) by indicators: noise $(87,22 \pm 0,98) \mathrm{dB}$ LA eq. (for electric train drivers) and $(91,15 \pm 0,87) \mathrm{dB}$ LA eq. (for drivers' assistants), which exceeds the TLV by $7-11 \mathrm{~dB}$ LA eq.); by general vibration (by the « $Z$ » axis $(117,48 \pm 3,09) \mathrm{dB}$, the TLV is 107 , and by the «Y» axis $(121,25 \pm 3,47) \mathrm{dB}$, the TLV is 112 ) and Class 3.1 (harmful, $1^{\text {st }}$ degree) by indicators of the microclimate. In general, conditions and the character of work of electric train drivers and their assistants refer to Class 3.2.

The certification of workplaces of ETD shows that all harmful production factors identified in the course of the study affect the body of drivers almost within the entire shift - from 93,52\% to $100 \%$ of the working time.

Taking into account the work experience, a body mass index was calculated for both groups, waist size (WS) was measured. It is determined that with increase of the work experience these indicators significantly increase, which points to the abdominal nature of obesity and is one of the criteria of developing a metabolic syndrome.

Laboratory studies revealed a significant difference between the biochemical parameters of a lipidogram and glucose levels in drivers and in the control group (Table 1).

When comparing the studied indicators in the experienced subgroups (SGs), a significant difference ( $p<$ $0,05)$ was found in the main and control groups with work experience of $21-30$ years (SG3). Signs of impaired fat metabolism in drivers according to the lipidogram corresponded to the values of anthropometric indicators (the general cholesterol, triglycerides, lipoproteids of low density, were significantly increased in ETD).

The formation of abdominal obesity, dyslipidemia and increased blood sugar in drivers was the basis for developing a metabolic syndrome (MS), associated with CVS diseases. When analyzing the statistical and spectral indicators of HRV, it was found that sympathicotonia was dominated (Fig. 1).

The state of sympathicotonia contributes to the increase of blood pressure, for the study of changes of which, DMAT was made. The variability of systolic arterial pressure (SAT) during a day was higher by $42 \%$, the variability of SAT at night was higher by $64 \%$. The indicators of the time index (TI) were used in order to summarize cases of high blood pressure (Fig. 2).

The state of situational anxiety was a clinical manifestation of sympathicotonia in ETD, prevailing 3 times, with the rate of $(48,99 \pm 2,51) \%$ vs. $(15,52 \pm$ $3,36) \%$ in the control group, indicating the availability of emotional stress due to the action of permanent stressors and causing body exhaustion.

According to the ultrasound heart examination, it is found that with the increase of the work experience there are developed significant changes in the geometry of the left ventricle (LV) - Table 2 .

This dynamics indicates a spherical remodeling of the left ventricle, which is a feature of changes in the heart shape and the increase of the work experience: there is an increase in the LV wall thickness, and then with the fibrosis progression - a parallel process of LV stretching in the lumbar size and decreasing the stroke volume (SV) in SG4.

The increase in the minute circulatory volume in SG3, but its decrease in SG4 due to decreasing SV, despite further increase in the heart rate, indicates not economical heart work and reducing adaptive capacity of the myocardium.

A doppler examination of the neck and brain vessels revealed structural changes in the wall of the carotid artery - increase in the intima-media com-

Laboratory indicators in ETD $(\mathrm{n}=398)$ and ETW $(\mathrm{n}=116), M \pm \mathrm{m}$

\begin{tabular}{|l|c|c|}
\hline \multicolumn{1}{|c|}{ Indicator } & ETD & ETW \\
\hline General cholesterol, $\mathrm{mmol} / \mathrm{l}$ & $4,98 \pm 0,28^{*}$ & $4,31 \pm 0,29$ \\
\hline Triglycerides, $\mathrm{mmol} / \mathrm{l}$ & $1,82 \pm 0,04^{*}$ & $1,59 \pm 0,03$ \\
\hline Lipoproteids of low density, mmol/1 & $3,11 \pm 0,03^{*}$ & $1,75 \pm 0,04$ \\
\hline Lipoproteids of high density, $\mathrm{mmol} / 1$ & $1,18 \pm 0,02^{*}$ & $1,32 \pm 0,04$ \\
\hline Blood glucose, $\mathrm{mmol} / \mathrm{l}$ & $5,48 \pm 0,32^{*}$ & $4,78 \pm 0,25$ \\
\hline
\end{tabular}

Note. ${ }^{*}$ The difference is significant between similar indicators of the surveyed groups $(p<0,05)$. 

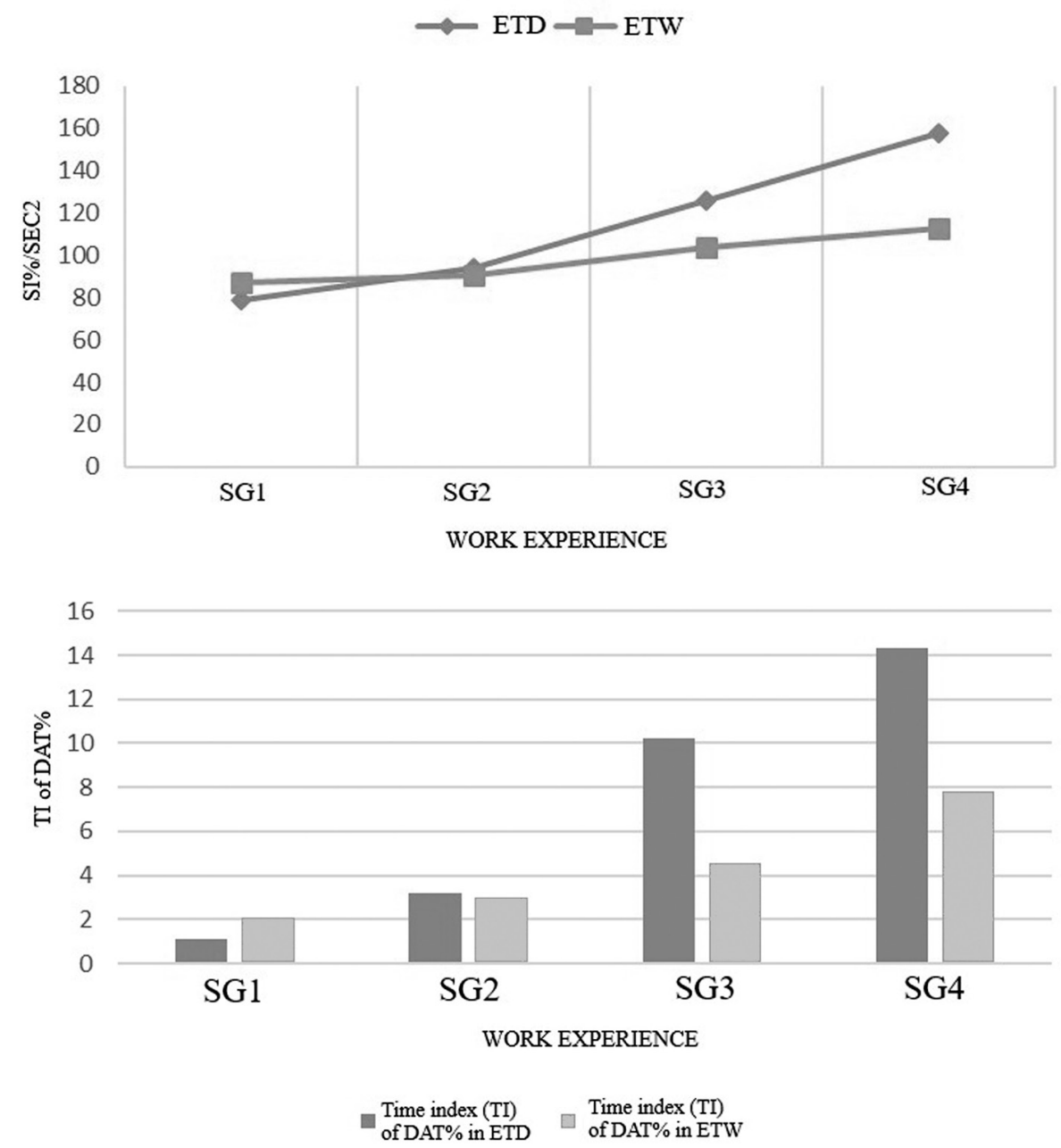

Fig. 1. Dynamics of the strain index of regulatory systems in the main and control groups depending on the work experience
Fig. 2. Dynamics of TI of DAT in ETD and ETW with the increase of the work experience plex (IMC), indicating early manifestations of atherosclerosis in the main group with the significant difference $(p<0,05)$ in the control group in SG3.

The study of the microcirculatory tract shows that after 20 years of work experience in SG3 in a significantly $(\mathrm{p}<0,05)$ higher percentage of workers there are recorded structural changes in the capillaries, indicating the disorders in the microcirculation system and increase in the blood pressure. An analysis of the response options to the dosed physical samples showed an increase in the percentage of hypertensive reactions. The obtained indicators point to the risk of occurrence and development of hypertension in drivers.

The generalized prognostic estimation of risk factors, working conditions and work experience in drivers for probability of development of diseases of the cardiovascular system is presented in Table 3.

The availability of high level of situational anxiety ( $>45$ ), which increases the risk of CVS diseases by
10,6 times $-\mathrm{OR}=10,6(6,30-18,0)$ can be used for the maximum prognostic assessment in increasing the probability of developing CVS pathology, exceeding the limits of normative levels of vibration increases the risk of CVS pathology by 7 times $\mathrm{OR}=7,0(3,29-15,0)$, exceeding the limits of noise levels - by 5,5 times $-\mathrm{OR}=5,5(2,95-10,3)$, that of indicators of the work experience of more than 20 years - by 3,5 times $-\mathrm{OR}=3,5(1,77-7,0)$.

Among individual clinical signs in drivers, which most significantly increase the risk of CVS pathology, is a metabolic syndrome $-\mathrm{OR}=4,1$. Thus, a negative impact of a combination of adverse production factors on the body of drivers resulted in characteristic changes after 20 years of employment.

In this, the change in the body reactivity under the influence of a stressful character of the work plays a leading role, and the reduction of the adaptive-compensatory capabilities of CVS is one of mechanisms of hypertension 
The results of ultrasound heart examination in the main $(n=398)$ and control groups $(n=116)$ depending on the work experience, $M \pm \mathrm{m}$

\begin{tabular}{|c|c|c|c|c|c|c|}
\hline \multirow{3}{*}{ Indicator } & \multicolumn{6}{|c|}{ Work experience } \\
\hline & \multicolumn{2}{|c|}{ SG2 } & \multicolumn{2}{|c|}{ SG3 } & \multicolumn{2}{|c|}{ SG4 } \\
\hline & ETD $n=84$ & ETW $n=26$ & ETD $n=123$ & ETW n $=35$ & ETD $n=82$ & ETW $n=26$ \\
\hline Aorta diameter, $\mathrm{cm}$ & $3,62 \pm 0,07$ & $3,45 \pm 0,06$ & $3,88 \pm 0,06^{*}$ & $3,53 \pm 0,05$ & $3,96 \pm 0,06^{*}$ & $3,56 \pm 0,06$ \\
\hline $\begin{array}{l}\text { Left ventricular wall } \\
\text { thickness, cm }\end{array}$ & $2,26 \pm 0,06$ & $2,10 \pm 0,05$ & $2,32 \pm 0,04^{*}$ & $2,19 \pm 0,04$ & $2,37 \pm 0,03^{*}$ & $2,22 \pm 0,04$ \\
\hline $\begin{array}{l}\text { Final diastolic } \\
\text { volume, } \mathrm{ml}\end{array}$ & $138,49 \pm 11,58$ & $128,73 \pm 9,52$ & $152,56 \pm 10,36^{*}$ & $137,11 \pm 9,16$ & $148,54 \pm 9,98$ & $138,104 \pm 9,470$ \\
\hline $\begin{array}{l}\text { Final systolic } \\
\text { volume, } \mathrm{ml}\end{array}$ & $46,25 \pm 5,11$ & $40,12 \pm 4,22$ & $54,27 \pm 4,89^{*}$ & $42,32 \pm 4,31$ & $58,46 \pm 5,21^{*}$ & $43,18 \pm 4,17$ \\
\hline Stroke volume, $\mathrm{ml}$ & $92,28 \pm 5,27$ & $88,54 \pm 5,12$ & $98,32 \pm 4,89 *$ & $92,95 \pm 5,04$ & $90,52 \pm 5,22$ & $95,87 \pm 5,16$ \\
\hline Ejection fraction, $\%$ & $66,21 \pm 3,51$ & $68,72 \pm 4,27$ & $64,23 \pm 4,39$ & $67,87 \pm 4,12$ & $60,81 \pm 4,47$ & $66,95 \pm 4,42$ \\
\hline $\mathrm{E} / \mathrm{A}$ & $1,25 \pm 0,04$ & $1,26 \pm 0,03$ & $1,16 \pm 0,03$ & $1,25 \pm 0,03$ & $1,03 \pm 0,05^{*}$ & $1,24 \pm 0,03$ \\
\hline $\begin{array}{l}\text { Myocardial mass } \\
\text { index, } \mathrm{g} / \mathrm{m}^{2}\end{array}$ & $77,47 \pm 3,92$ & $73,89 \pm 3,34$ & $81,25 \pm 3,21$ & $78,38 \pm 3,31$ & $88,72 \pm 2,11^{*}$ & $81,45 \pm 2,87$ \\
\hline $\mathrm{HR}, \mathrm{b} / \mathrm{min}$ & $71,51 \pm 4,21$ & $68,12 \pm 3,34$ & $76,26 \pm 3,15^{*}$ & $68,89 \pm 3,31$ & $78,43 \pm 4,28$ & $69,93 \pm 3,28$ \\
\hline $\begin{array}{l}\text { Minute volume of } \\
\text { blood circulation, } 1 / \mathrm{min}\end{array}$ & $6,38 \pm 0,07$ & $5,98 \pm 0,06$ & $7,45 \pm 0,06^{*}$ & $6,31 \pm 0,05$ & $7,24 \pm 0,05$ & $6,51 \pm 0,05$ \\
\hline
\end{tabular}

Note. *The difference is significant between similar indicators of the surveyed groups $(p<0,05)$.

development in drivers. Thus, the most dangerous for drivers is a threat of occurrence and development of hypertension, which occurs on the background of disorders in the carbohydrate and fat metabolism with the development of a metabolic syndrome.

The term of work experience of 20 years (SG3) can be considered as a the threshold criterion of risk, when the probability of developing CVD increases by 3 times as compared with the subgroup with the work experience up to 10 years (SG1).

The dynamics of the pathological process can be represented by the following scheme: health indicators in ETD and ETW (SG1) do not differ significantly; in ETD (SG2) vegetative dysfunction is noted with the increase in the tone of the sympathetic division of the vegetative nervous system; in ETD (SG3) - on the background of the vegetative imbalance there are appeared structural changes in the CVS and liver, which become deeper and irreversible in SG4.

The analysis of the state of health of electric train drivers and their assistants, as well as the results of instrumental and laboratory studies, enabled to form a new strategy of early diagnostics taking into account the state of the most vulnerable organs and systems

Tahle 3

Prognostic estimation of risk factors, working conditions and work experience of drivers for probability of development of diseases of the cardiovascular system

\begin{tabular}{|l|c|c|c|}
\hline \multirow{2}{*}{ Sign } & \multicolumn{2}{|c|}{ Heart rate in ETD according to risk factor: } & \multirow{2}{*}{$\begin{array}{c}\text { Estimation of OR } \\
\text { (95 \% CI) }\end{array}$} \\
\cline { 2 - 4 } & $\begin{array}{c}\text { in the availability of } \\
\text { the studied risk factor }\end{array}$ & $\begin{array}{c}\text { in the absence of the } \\
\text { studied risk factor }\end{array}$ & $10,6(6,30-18,0)$ \\
\hline High level of situational anxiety & $110 / 195(56,4 \%)$ & $22 / 203(10,8 \%)$ & $7,0(3,29-15,0)$ \\
\hline Exceeding the normative levels of vibration & $124 / 307(40,4 \%)$ & $8 / 91(8,8 \%)$ & $5,5(2,95-10,3)$ \\
\hline Exceeding the normative noise levels & $119 / 285(41,8 \%)$ & $13 / 113(11,5 \%)$ & $3,5(1,77-7,0)$ \\
\hline Work experience of more than 20 years & $95 / 205(46,3 \%)$ & $12 / 61(19,7 \%)$ & $4,1(2,61-6,40)$ \\
\hline Metabolic syndrome & $73 / 135(54,1 \%)$ & $59 / 263(22,4 \%)$ & $2,9(1,86-4,50)$ \\
\hline Smoking & $88 / 197(44,7 \%)$ & $44 / 201(21,9 \%)$ & $2 \%$ \\
\hline
\end{tabular}

Note. Heterogeneity of the studied risk factor $p<0,001$. 
in drivers (liver and CVS); to develop preventive measures; to recommend medical examination taking into account the work experience; to offer means of correction of the vegetative dysfunction at early stages.

The identified regularities and main directions of preventive measures are schematically presented in Table 4.

Differentiation of dispensary groups of ETD is carried out with account of the work experience: Dispensary group 1: additional examinations and medical treatment are not required. It is advisable to undertake preventive measures; Dispensary group 2: for biochemical blood tests - analysis of lipidogram, glucose, prothrombin index (PTI). If disorders in lipid metabolism is observed after preventive measures, hypolipidemic therapy is required; Dispensary group 3 : analysis of lipidogram, glucose level, PTI in blood, measurement of waist and IMT calculation, ultrasound of the heart and liver, intra- and extracranial Doppler with determination of IMC, capillaroscopy, heart rate variability, bicycle ergometry, daily monitoring of AT, if necessary; Dispensary group 4: if any changes occur - their medical correction is needed.

Prophylaxis of development of pathological changes in drivers includes:

- development and improvement of methods of protection against harmful production factors (vibration and noise) in order to minimize their impact on the body, implementation of technical modernization of workplaces;

- optimization of work and rest regimens, organization of healthy eating, psychological relief, use of health improving procedures at resting points;

- informing workers on adverse effects of high blood pressure and other risk factors to life expectancy and work activity, importance of blood pressure control;

- diet with restriction of fats of animal origin;

- restrictions on the use of alcohol, salt;

- refusal of smoking;
- physiotherapy, self-training;

- dosed physical activity, exercise therapy.

\section{Conclusion}

1. It has been established that the work of electric train drivers refers to Class 3.2 (harmful, hard, $2^{\text {nd }}$ degree) according to the criteria of the State Classification of Work, 2014.

2. According to the results of the research, the degree of severity of pathological changes in electric train drivers and their assistants in the relevant subgroups has been determined depending on the work experience: in SG3 - on the background of vegetative imbalance, structural and functional changes in the CVS and liver are appeared, which become deeper and irreversible in SG4. The most predictable nosologiesin drivers were: hypertension, metabolic syndrome, non-alcoholic fatty liver disease as well as comorbid pathology on the background of vegetative dysfunction, which was the basis for development of the hepatocardial continuum.

3. The prognostic estimation of the increase in probability of developing the pathology of the CVS in ETD is given. According to the degree of influence on the state of the CVS, risk factors for workers are as follows: high level of situational anxiety, exceed of the limit of normative levels for vibration, exceeding the limits of normative noise levels, work experience of more than 20 years, availability of the metabolic syndrome, smoking.

4. Differentiation of dispensary groups with the proper number of health-improving measures for drivers is carried out according to the work experience.

5. A combination of health procedures has been developed for electric train drivers and their assistants as the main preventive measure against development of CVS pathology due to the influence of working conditions.

Risks of adverse effects of production factors on the body of ETD; means of their overcoming

\begin{tabular}{|c|c|c|c|}
\hline \multicolumn{3}{|c|}{ Influence of a combination of unfavorable production factors on the body of ETD } \\
\hline $\begin{array}{c}\text { I. Metabolic disorders in the } \\
\text { body }\end{array}$ & $\begin{array}{c}\text { II. Vegetative disfuctions in } \\
\text { the body }\end{array}$ & $\begin{array}{c}\text { III. High level of situational } \\
\text { anxiety }\end{array}$ & $\begin{array}{c}\text { IV. Structural and functional } \\
\text { changes in the body }\end{array}$ \\
\hline $\begin{array}{l}\text { Risk of development of hypertension, metabolic syndrome, non-alcoholic fatty liver disease in ETD on the background of } \\
\text { vegetative dysfunction }\end{array}$ & $\begin{array}{c}\text { Formation of dispensary } \\
\text { groups }\end{array}$ & Correction of vegetative dysfunction \\
\hline $\begin{array}{c}\text { Prevention of development of pathological } \\
\text { changes }\end{array}$ & \begin{tabular}{c} 
Cong \\
\hline
\end{tabular}
\end{tabular}




\section{References}

1. Alekseychuk O. Yu., Tkachishin V. S., Tkachishina N. Yu., Arustamyan O. M. (2014), "Peculiarities of working conditions of locomotive drivers and their assistants", Dovkillya ta zdorovya, 4, 29-33.

2. Tkachishin V. S., Arustamyan O. M., Tkachishina N. Y., Alekseychuk O. Y. (2015), "Sanitary and hygienic assessment of the production process of locomotive crews", in Aktual'ni pytannya profilaktychnoyi medytsyny, Materials of Conference, Kyiv, Ukraine, 15-16.

3. Alekseychuk O. Yu., Tkachishina N. Yu., Tkachishin V. S., Arustamyan O. M. (2015), «Working conditions and morbidity of locomotive drivers", Aktualnye problemy transportnoi meditsiny, 4, 17-32.

4. Knytilo S. S. et al. (2012), "Assessment of health railway workerswhose work is related on train safety movement", Medytsyna transportu Ukrainy, 2, 66-67.

5. Chernyuk V. I., Bobko N. A., Gadayeva D. O. (2018), "Differences in blood circulation functioning in truck drivers related to age, experience and work regime", Ukrainian Journal of Occupational Health, 2, 20-28. https://doi.org/10.33573/ujoh2018.02.020.

6. Tkachishin V. S., Alekseychuk O. Y., Tkachishina N. Y., Kanevsky O. S. (2011), "Frequency of occurrence of pathological processes of internal organs among employees of locomotive brigades", Medytsyna transportu Ukrainy, 2, 49-51.

7. Korobchansky O. O., Grigoryan O. V. (2018), "Morbidity analysis of workers performing high-risk work", Ukrainian journal of medicine, biology and sports, 3 (6), 221-227.

8. Kryukov N. N., Gaberman O. E. (2015), «Profession as a risk factor for cardiovascular diseases", in Nepreryvnoye professional'noye obrazovaniye - zalog povysheniya kachestva meditsinskoy pomoshchi v pervichnom zvene, Materials of Conference, Samara, 152-154.

9. Viktorov V. S. et al. (2015), "Problems of prevention of the adverse effects of night work on the health of workers", in Professiya izdorov'ye, Materials of Conference of XI All-Union Congress, (Moscow, 27 et al. 29 November 2012), Moscow, 116-118.

10. Kozyaryn I. P., Ivakhno O. P., Dubova N. F. (2014), "Overweight and its prevention", in "Chornobyl: Ecology and Health", 71-83.

11. Troshina M. Yu. (2013), «Organization of rational nutrition of railways workers, requirements for the range of products", Sovremennyye problemy nauki $i$ obrazovaniya, 1, 1-9.

\section{Яворовсыкий О. П.' ' Ткачишина Н. Ю.'2, Казнодій А. В.' ФІВІOАОГО-ГІГІЕНІЧНА ОЩНКА УМОВ ПРАШ Й ЗАОРОВ'Я МАШИНІСТІВ

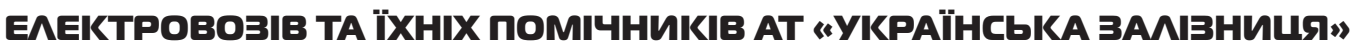

'Нашіональний медичний університет імені О. О. Богомольшя, М. Київ

${ }^{2}$ Київська клінічна лікарня № 2 на залізничному транспорті філії «பОЗ» ПАТ «УЗ»

Bcmyn. На сучасному етапі працівники локомотивних бригад (ПЛБ) виконують основну функцію транспортної галузі - забезпечують безперебійний рух з високою відповідальністю за перевезення пасажирів і різноманітних вантажів. Технологія виробничого процесу на залізничному транспорті обумовлює наявність на робочих місцях ПЛБ комплексу шкідливих факторів виробничого середовища та трудового процесу.

Мета дослідження - оцінити умови праці ПЛБ за показниками важкості та напруженості трудового процесу, шкідливості й небезпечності факторів виробничого середовища, розробити зі застосуванням сучасних методів математичного аналізу прогностичну модель щодо комплексної оцінки впливу шкідливих чинників виробничого середовища та трудового процесу як факторів ризику розвитку патологічних змін в організмі ПЛБ, зокрема, сердечнососудистої системи (ССС).

Матеріали та методи дослідження. Гігієнічні дослідження та визначення умов праці проводилися відповідно до нормативної документації. Клініко-інструментальні дослідження проводились з використанням сучасного діагностичного обладнання. Для прогностичної оцінки вірогідності розвитку патології ССС залежно від наявності окремих клінічних чи виробничих чинників ризику розроблена прогностична модель статистично значимих чинників ризику з оцінкою для них відношення шансів з наступним узагальненням їх за принципами мета-аналізу та визначенням гетерогенності впливу (Higgins's I2 test) на здоров'я ПЛБ.

Результати. За результатами проведених досліджень праця машиністів електровозів та їхніх помічників за критеріями ГКП 2014 року в цілому відповідає класу 3.2; визначено ступінь вираженості патологічних змін у машиністів електропоїздів та їхніх помічників у відповідних підгрупах залежно від стажу роботи. Найпрогнозованішими нозологіями у ПЛБ є: артеріальна гіпертензія, метаболічний синдром, неалкогольна жирова хвороба печінки, а також коморбідна патологія на фоні вегетативної дисфункції, що є основою для розвитку гепатокардіального континууму. Надано прогностичну оцінку щодо підвищення вірогідності розвитку патології ССС у ПЛБ. Диференціація диспансерних груп і оздоровчих заходів відповідного об’єму у ПЛБ відбувається з урахуванням стажу роботи. Висновки. Широка імплементація в практику заходів профілактики залежно від диференціації диспансерних груп дозволить ефективно знизити ризики виникнення патологічних змін ССС залежно від стажу роботи.

Ключові слова: працівники локомотивних бригад, умови праці, здоров'я 
ISSN 2223-6775, Ukrainian Journal of Occupational Health, 2020, 16 (2), 96-103

\section{Яворовский А. П.', Ткачишина Н. Ю.2', Казнодий А. В.' ФИЗИОЛОГО-ГИГИЕНИЧЕСКАЯ ОЧЕНКА УСАОВИЙ ТРУАА И ЗАОРОВЬЯ МАШИНИСТОВ ЭАЕКТРОВОВОВ И ИХ ПОМОШНИКОВ АО «УКРАИНСККАЯ

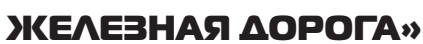

'Нашиональный медицинский университет имени А. А. Богомольша, г. Киев

${ }^{2}$ Киевская клиническая больниша № 2 на железнодорожном транспорте филиала «ШЗО «ПАО «УЗ»

Вступление. На современном этапе работники локомотивных бригад (РЛБ) выполняют основную функцию транспортной отрасли - обеспечивают бесперебойное движение с высокой ответственностью при перевозке пассажиров и различных грузов. Технология производственного процесса на железнодорожном транспорте обусловливает наличие на рабочих местах РЛБ комплекса вредных факторов производственной среды и трудового процесса.

Цель исследования - оценить условия труда РЛБ по показателям тяжести и напряженности трудового процесса, вредности и опасности факторов производственной среды; разработать комплексную оценку влияния вредных факторов производственной среды и трудового процесса как факторов риска развития патологических изменений в организме РЛБ с применением современных методов математического анализа прогностической модели.

Материалы и методы исследования. Гигиенические исследования и определения условий труда проводились в соответствии с нормативной документацией. Клинико-инструментальные исследования проводились с использованием современного диагностического оборудования. Для прогностической оценки достоверности развития патологии сердечно-сосудистой системы (ССС) в зависимости от наличия отдельных клинических или производственных факторов риска разработана прогностическая модель статистически значимых факторов риска с оценкой для них отношения шансов со следующим обобщением их по принципам метаанализа и определением гетерогенности влияния (Higgins's I2 test) на здоровье РЛБ.

Результаты. По результатам проведенных исследований труд машинистов электровозов и их помощников по критериям «Гигиенической классификации труда» 2014 года в целом отвечает классу 3.2. Определена степень выраженности патологических изменений у машинистов электропоездов и их помощников в соответствующих подгруппах в зависимости от стажа их работы. Наиболее прогнозируемыми нозологиями у РЛБ являются: артериальная гипертензия, метаболический синдром, неалкогольная жировая болезнь печени, а также коморбидная патология на фоне вегетативной дисфункции, которая является основой для развития гепатокардиального континуума. Представлена прогностическая оценка относительно повышения достоверности развития патологии ССС у РЛБ. Дифференциация диспансерных групп и соответствующего объема оздоровительных мероприятий у РЛБ происходит с учетом стажа работы.

Bыводы. Широкая имплементация в практику мероприятий профилактики в зависимости от дифференциации диспансерных групп позволит эффективно снизить риски возникновения патологических изменений в зависимости от стажа работы.

Ключевые слова: работники локомотивных бригад, условия труда, здоровье

ORCID ID співавторів та їхній внесок у підготовку та написання статті:

Яворовський О. П. - формування концепції та методології, оцінка та розробка заходів профілактики, написання статті; Ткачишина Н. Ю. (ORCID ID 0000-0001-9828-4977) - проведення аналітичного дослідження, проведення гігієнічних і клініко-інструментальних досліджень, оцінка та розробка заходів профілактики, написання статті; Казнодій A. В. (ORCID ID 0000-0001-9500-4167) - проведення клініко-інструментальних досліджень, статистичний аналіз, написання статті.

Інформація щздо джерел фінансування дослідження: дослідження виконано за рахунок власний ресурсів, у рамках дисертаційної роботи Н. Ю. Ткачишиної «Профілактика та корекція структурно-функціональних змін в органах і системах працівників локомотивних бригад з різним стажем роботи».

Надійшла: 25 березня 2020 р.

Прийнята до друку: 29 квітня 2019 р.

Контактна особа: Ткачишина Наталія Юріївна, Київська клінічна лікарня № 2 на залізничному транспорті філії «ЦОЗ» ПАТ «УЗ», буд. 9, Повітрофлотський просп., м. Київ. Тел.: + 380972551401.

Електронна пошта: tkachishin@i.ua 